\title{
Employment practices in Japan's automobile industry: the implication for divergence of employment systems under globalization
}

\author{
Mari Yamauchi ${ }^{1}$ (D) \\ Published online: 9 September 2020 \\ (c) The Author(s) 2020, corrected publication 2020
}

\begin{abstract}
This paper analyses recent developments in HR practice toward core white collar employees at Japan's major automobile companies. It confirms there have been incremental but substantial changes in key HR policies such as compensation and the ranking system, but also finds that traditional long-term employment continues to be practiced at most firms. It further observes that Japan's auto companies have introduced global HR polices earlier than have Japanese firms in comparable sectors. This, however, has not resulted in the alignment of policies toward those of overseas operations, which one often finds in other Japanese industries such as finance and pharmaceuticals. This would indicate that different trajectories of change are emerging in employment practices - that is, diversification in employment systems is expanding - according to sector (or, the products and services firms offer). This paper also analyses several background factors propelling such divergence, and suggests possible future constellations of employment systems among large elite firms in Japan. In these ways this study contributes to the debate on the effects of globalization on divergence and convergence of employment systems.
\end{abstract}

Keywords Employment systems · Globalization · Divergence and convergence · Institutions · Japan

Mari Yamauchi

myamauchi@gl.aiu.ac.jp

1 Akita International University, Akita, Japan 


\section{Introduction}

Lifetime or long-term employment (hereafter, LTE) and the 'seniority-plus-merit principle $^{1}$, or nenko, the cornerstone of traditional Japanese human resource management (Dore 1973; Koike 1987), has come under significant pressure due to slow economic growth and intensified global competition, and many authors have pointed to erosion and a diversification in employment systems as a result (Morishima 1995; Miyajima et al. 2003; Miyamoto 2006; Yamauchi 2013, 2016). Other observers stress that institutions which have long undergirded the traditional employment system-e.g., new graduate-centred hiring or internal promotion-are actually hindering the transition of Japan's labour market into one with greater liquidity and diversity that can meet the challenges posed by a rapidly changing and globalizing technological and product environment where international competition over talent is intensifying. (Waldenberger 2016; Conrad and Mayer-Ohle 2019).

Globalization is thus a key factor in determining the direction of HRM among large Japanese MNCs. In this vein, some scholars (Hirano 2006; Olcott 2009; Ono 2007; Yamauchi 2013, 2016) have studied differences in HRM practice according to ownership_-Japanese vs. foreign-finding that foreign MNCs operating in Japan have been a major factor driving divergence in employment policy. Others have conducted sector-specific research into HR practices of major Japanese corporations, concluding that deviation from the traditional employment model has been most pronounced in sectors such as finance (securities companies) and pharmaceuticals (Yamauchi 2013, 2016; Suda 2015, 2017), where global competitors have rapidly expanded operations in Japan, taking market share from Japanese local players as soon as local markets were deregulated.

The key factor driving these developments is intensified competition with new foreign players-following deregulation and globalization of product and service markets-which has quickly led to fierce competition over human resources in local labour markets. Thus, growing divergence in HRM practice in Japan appears to reflect differences in the relative competitive strengths or weaknesses of firms; these differences manifest themselves only after product and service markets are deregulated and, as a result, global competitive pressures intensify. In other words, in sectors where strong institutional pressures continue to prevail, and thus global competitive pressures are subdued or non-existent, relative competitive advantages or disadvantages are not an issue, implying firms in such sectors have little motivation to change employment practices. In deregulated sectors, however, relative advantages and disadvantages do manifest themselves and, where Japanese companies exhibit little competitive strength, foreign players are able to quickly expand operations in local markets, forcing native firms to adapt and change.

The present study is exploratory in nature. It examines HR practice within Japan's auto sector and discusses, more broadly, how the employment system has been modified or adjusted in recent decades in those sectors where the traditional Japanese

\footnotetext{
${ }^{1}$ Nenko is conventionally translated as either Japan's 'seniority-based' or 'seniority-plus-merit based' employment system (Sako 1997). The latter is adopted in this study.
} 
model has contributed to Japanese firms establishing strong positions within global markets (Porter and Takeuchi 2000; Fujimoto 2003). It then addresses the implications of these findings for change and diversification of employment systems in Japan, presenting a hypothetical overview of divergence in light of findings from other sectors.

Since the turn of the century, the auto sector has also seen radical innovation (e.g., the electric vehicle, automatic driving, car sharing) mainly driven by start-up firms in the US, and involving a number of international and domestic business tieups and alliances. However, researches on recent developments in HRM in this sector have been limited. This paper examines the effects of such innovation on HRM for core white collar employees in the sector. It also looks at how global HR, or policies to align HR practices across global operations, are being introduced in the sector. To the extent Japanese auto sector firms enjoy competitive advantages in global markets, we would expect HR policies to evolve based on principles of the traditional employment model, while introduction of global HR should entail adoption of core Japanese practices by overseas operations.

The following section introduces prior studies which have addressed change and diversification in HRM practice in Japan; it then reviews recent developments in HRM in the automobile and other comparable industries, focusing in particular on the impact of globalization. Section 3 covers research methods and provides profiles of the firms which make up this paper's case study. Empirical findings are reviewed in Sect. 4, with summary findings presented in Sect. 5. Finally, Sect. 6 presents conclusions and offers possible scenarios for future trajectories of divergence among employment systems in Japan.

\section{Prior studies}

\subsection{Divergence in employment systems in Japan}

The first wave of researches addressing divergent employment systems in Japan were conducted in the form of surveys focusing on key HRM parameters such as type of employment, criteria for employee evaluation, and attitudes toward corporate governance reform (Morishima 1995; Miyajima et al. 2003; Miyamoto 2006). For example, Morishima (1995) divided companies into three categories based on degree of externalization of employment and extent of adoption of competitive appraisal and pay practices. Miyajima et al. (2003) and Miyamoto (2006) grouped firms into three and four patterns (respectively) according to type of employment (LTE vs. non-LTE) and pay structure (nenko vs. $\mathrm{PRP}^{2}$ ); they then analysed this data in relation to attitudes toward corporate governance reform.

Increased activities by global investors have also invited a number of studies focusing on the correlations between corporate governance parameters (board structure, use of managerial stock options, type of financing, level of foreign ownership,

\footnotetext{
2 performance-related pay.
} 
and the like) and HRM (Ahmadjian and Robinson 2001; Ahmadjian and Robbins 2005; Abe and Hoshi 2007; Jackson 2007). Ahmadjian and Robbins (2005) reported that the higher the level of foreign ownership, the more likely a firm is to adopt downsizing (though the effect is moderated if the firm in question has close ties with domestic financial or corporate groups). Abe and Hoshi (2007) have investigated the relationship between foreign ownership and HR policy, reporting some correlations for practices such as fast track, but no significant correlations with regard to core pay structures. Jackson (2007) finds a relationship between board structure and the use of managerial stock options, and merit pay systems and LTE; however, he concludes that foreign ownership does not significantly impact core employment policies. Jacoby (2007) studied the activities of foreign financial investors in Japan and also concluded that their impact on HR policies, and even corporate governance reform as a whole, has been modest at best. More recently, however, Kubo (2018) found that foreign ownership and outside director ratio significantly affect firms' decent work policies, possibly because of investors' incentive to raise profitability or enhance reputation.

\subsection{HRM in the automobile sector}

Sector-specific researches have been conducted mainly via case studies, which allows for detailed observation of HR practices; such work has tended to focus on skill formation and production methods at the most representative firms within major sectors. In particular, Japan's automobile manufacturers have attracted researches across a range of academic disciplines, scholars emphasizing efficient production systems and unique HRM practices as sources of global competitive advantage (Koike 1987; Koike et al. 2001; Kumazawa and Yamada 1989; Fujimoto 1997, 2001; MacDuffie and Krafcik 1992). For example, Koike examined human resource deployment among shop floor workers, finding that they acquire various skills, and learn to conduct multiple tasks through job rotation and OJT over the course of LTE, but that such deployment is not necessarily simply seniority-based but often reflects individual skill level acquired. Koike also claims that Japanese automobile companies have introduced some key Japanese HR practices into operations abroad (2008). In their study of 70 auto assembly plants from 24 firms, MacDuffie and Krafcik (1992) concluded that the existence of a skilled, highly motivated and flexible work force was the premise for (Japanese) lean production. Fujimoto $(1997,2001)$ examined auto engineers in research and development as well as in manufacturing (white collar employees) and found that most engineers rotate within specialized fields (e.g. body, engine, chassis, material, design, etc.) during their early growth stages, while some move beyond such specific fields as they become more senior in rank. Fujimoto also claims that mid-career hiring does occur as firms come across desirable candidates. Yashiro (2017) confirmed that these policies are still valid at Japanese auto companies and that long-term employment has been maintained at most firms in the sector, while also reporting substantial deviation from traditional HRM in Japan's investment banking industry. Figure 1 shows the trajectories of average employee tenures at major auto sector firms as compared to banks. 
Automobile

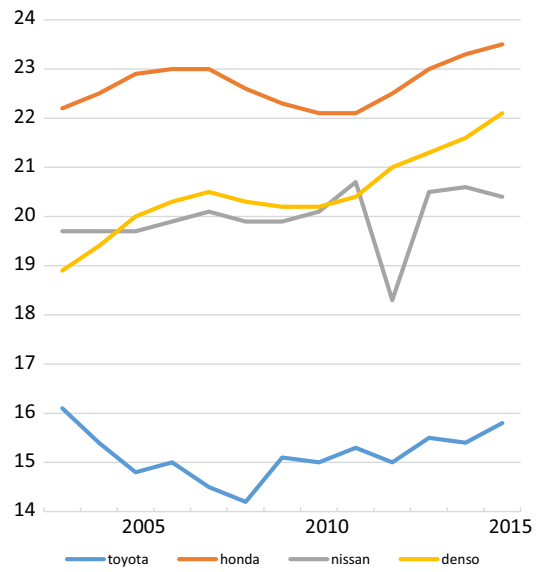

Finance

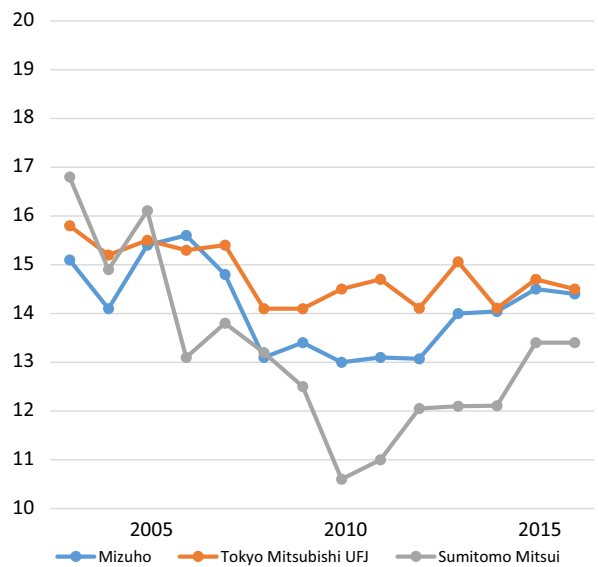

Fig. 1 Average tenures of employees at major companies in Japan's auto and financial sectors. Tenure covers all regular workers (white collar, blue collar, clerical) except for Toyota, where temporary workers are also included. Source: financial statements of each company

Reviewing automobile industries abroad, Appelbaum and Batt (1994) analysed and compared production methods and employment systems at auto sector companies in five countries: the US, Japan, Germany, Italy and Sweden. In this extensive research they alluded to production systems potentially converging toward the Japanese lean production system, which allows for both mass production and scientific quality control. Hunter and Katz (2012) actually found, in a comparative study of US auto sector companies and financial firms, that Japanese transplants in the US are oriented toward lean production and team organization despite the dominant pattern of mass production in local markets. They also found that, since the early 1980s, (Japanese) team working has spread at an uneven pace and with much diversity, even at the Big Three (Hunter and Katz 2012:1992), while non-union transplant assembly companies tend to follow Japanese-oriented forms of employment stabilization (2012:1994). Thelen (2014: 41) claims that collective bargaining in the US automobile industry declined partly because Japanese transplants resisted unionization. Building upon findings on the differences in HR practices of the two sectors, Hunter and Katz also claim that the way globalization influences employment relations is more industry-specific.

\subsection{HRM in other comparable sectors}

Recent literature in the area of comparative analysis argues that there is a degree of 'fit' between the type of innovation found in the industries of a specific country, and the skills that are nurtured under the particular institutional environment dominant in that country (Hall and Soskice 2001; Turner 2001; Whitley 1999). In the case of Japan, it is often claimed that the sector which has benefited most from the traditional employment system is automobile manufacture (Porter and Takeuchi 2000; 
Fujimoto 2003, 2018), because skill formation, based on long-term employment and the seniority-plus-merit principle in wage and promotion systems, fosters intense coordination among employees, enabling efficient production based on successful implementation of various kaizen activities and quality control measures.

However, studies focusing on other Japanese industries have often found stresses or conflicts between traditional Japanese employment methods and more universally common labour market practices dominant in these sectors. Such deviation is claimed to be a factor in relative weakness among Japanese MNCs in respective international markets, which in turn is promoting more explicit deviations (departures) from the traditional Japanese model.

For example, Suda's research $(2015,2017)$ comparing Japan's pharmaceutical and electric machinery industries found significant differences in HR policy; in the latter sector, marked divergence was observed between policies at Japanese companies versus foreign companies operating in Japan. More specifically, Japanese electric machinery companies continue to deploy traditional person-based grade systems, while foreign companies employ job-based grading. On the other hand, firms in the pharmaceutical industry do not display such divergence by ownership and, for example, recruitment of new graduates by occupation or job type were practiced at all seven major companies interviewed (4 Japanese and 3 foreign MNCs), ${ }^{3}$ while six of the seven had introduced job-based (as opposed to traditional ability- or person-based) criteria to rank employees. Such policies are more closely aligned with emerging standards in the industry's labour markets, which have become fluid due to the expansion of top foreign MNCs (e.g., Pfizer, Novartis) who have quickly taken advantage of local market deregulation so as to now even compete with major local players for leading positions within Japan.

Indeed, following the deregulation of the 1990-2000s, the expansion of foreign players into Japan's local product and labour markets has been pronounced in the pharmaceutical sector. As of 2015 more than half of the top 20 firms (by drug sales) are foreign players, and five within the top 10 are American and European firms; namely, Pfizer, MSD, Novartis, Astra Zeneka and Bayer (IQVIA 2016). Similarly, half of the top 20 firms who hire the most MRs in Japan are now subsidiaries of foreign pharmaceutical companies (MediSearch 2016). It should be noted that Takeda Pharmaceutical Company, which had long been Japan's largest drug maker, recently transformed its HR policies by inviting in a foreign (French) CEO in 2015 in order to accelerate global M\&A activities and enhance the firm's presence in a rapidly evolving industry landscape.

Yamauchi $(2013,2016)$ found that recent HR practices at Japanese financial companies have produced similar trajectories of change, with firms incorporating several of the HRM measures initially introduced by foreign MNCs. For example, both banks and securities companies have introduced individual annual base salaries, beyond the limits of existing ranks, by establishing separate job fields or employee categories (even with explicitly reduced job security in exchange for higher-paying salaries). In addition, firms in both sectors have established specialized career

\footnotetext{
3 Occupations include research, development, MR, manufacturing technologies, etc.
} 
courses which allow new graduates, before entering companies, to determine their professional tracks without being subject to the regular job rotation that HR departments have traditionally controlled. In this vein, the author found that technical and institutional pressures are important, concluding that core white collar workers at life insurance companies have experienced much more subdued change than have comparable employees at firms in other financial sub-sectors-a result of far less global competitive pressures faced by firms in this sector.

The author explained these differences as resulting from the interaction of technical and institutional characteristics related to the core products offered in this sector: The long-term nature of life insurance policies limits international transferability and short-term transacting of core products, leaving firms in the sector much less vulnerable to global competitive pressures yet more vulnerable to domestic institutional pressures (i.e., approval processes and inspections by local authorities). In contrast, securities firms, whose core products are highly internationally transferable and go through short transaction cycles, have exhibited the largest deviation from traditional practice among all financial sub-sectors-a reflection of the different nature and greater intensity of global competitive pressures faced in this area. Indeed, Nomura Securities Company, the largest securities firm in Japan, has even adopted Anglo-Saxon type HRM policies for staff in HQ in order to unify ranks and evaluation criteria for staff worldwide-this following its acquisition of the European and Asian operations of a collapsed Lehman Brothers.

Casper and Whitley (2004) also found that sub-sector differences matter in regard to the formulation of HRM practices that best cope with the challenges and risks associated with the production and implementation of particular products. Thus, in the area of software, development of middleware and application products occurs more efficiently within the institutional frameworks of liberal market economies, while ERP is a better fit with coordinated market economies because of the importance of incremental innovation through intensive coordination efforts. Yamauchi (2018) elaborated such findings, analysing SAP's success in light of the German institutional framework. In short, to understand diverging employment patterns, sector differences need to be carefully investigated and considered.

\subsection{Globalization and employment systems}

Several scholars of global HR claim that Japan's employment system is a major obstacle to the recruitment and retention of students from leading universities internationally due to companies' slow and internal promotion policies and the limited opportunities for employees hired from abroad (Conrad and Meyer-Ohle 2019; Waldenberger 2016). In this context, if large Japanese MNCs hope to attract strong foreign employees, they will likely need to transform domestic HR practices in the future, introducing globally unified HR policies that facilitate more individually tailored compensation and career development schemes. In other words, the decisions taken by Nomura and Takeda are legitimate responses to the challenges posed by global HR initiatives and appear likely to bear fruit. 
On the other hand, the subsequent woes experienced by both companies in the course of expanding their businesses abroad may also indicate that even properly designed new HR policies-which, in theory, should meet the challenges of a globalized labour market - do not necessarily bring desired results (at least not immediately). Indeed, similar trends can be observed in other countries. For example, after introducing Anglo-Saxon type HR and other management practices, Deutsche bank failed to establish the desired positions at its global investment banking businesses and, further, has recently been forced to curb global operations (this while American competitors were recording record profits during the same period). Such developments point to the difficulties firms transforming HRM may typically face in both global and local labour markets. In global markets, when already operating from a non-leading position, there is no guarantee a firm will attract top global talent even after transforming its HRM; in local markets, increased incompatibility with longembedded traditional labour market institutions may even put at risk recruitment of top local talent.

\section{Methods and profiles of case study companies}

In order to observe recent changes and developments in HRM policies and practices among auto sector companies, a case study, based on interviews with seven of Japan's most representative firms, was conducted between 2013 and early 2016. Six of these firms are vehicle manufacturers (four of passenger cars, two of trucks and buses) while another is Japan's top auto-parts maker. Importantly, this sample encompasses Japan's largest auto sector firms, which in aggregate manufacture approximately $70 \%$ of all passenger cars produced in Japan, thereby ensuring external validity. Given that the purpose of the current inquiry is to explore or investigate recent changes in Japanese auto sector firms' HRM policies and practices, conducting a case study based on interviews was deemed the most suitable approach, for this method enables detailed observation of the processes as well as the background of the change observed (Yin 2003). This method also provides a basis for rigorous comparison which takes into consideration individual companies' profiles.

The case study focuses primarily, but not exclusively, on university and graduate school graduates comprising white collar employees and managers (but not executives), including both engineers and administrative staff hired at the headquarter level. In prior literatures, these employees have received less attention than the sector's blue collar workers. Focus on white collar workers allows comparative analysis with HRM in other sectors including services, where blue collar workers are nonexistent or play far less important roles than their counterparts in manufacturing. Notwithstanding, interviews also prompted comments on blue collar workers and executive management deemed relevant and insightful, and so have been incorporated into this study.

In total, $18 \mathrm{HR}$ managers were interviewed over 10 visits, while two interviews were conducted with A Co., D Co., and G Co. In order to gauge the overall configuration of employment systems within the industry, semi-structured interviews covered the entire career paths of core white collar employees: Hiring practices (new 


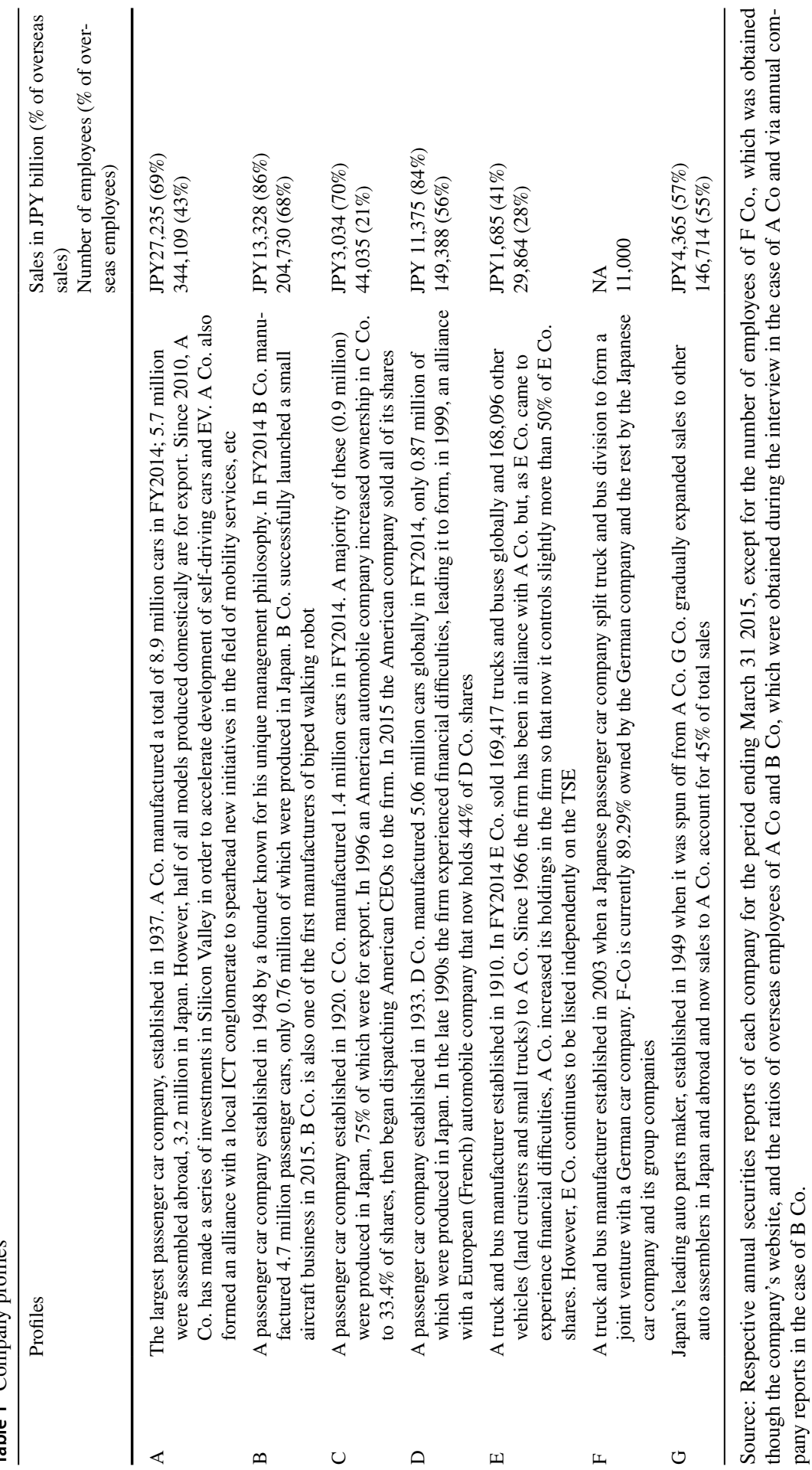


graduate vs. mid-career hires); retirement conditions (options for retirement and proportions of white collar employees actually continuing to work until retirement age); skill formation (job rotation coverage); and compensation and promotion (individual difference in compensation and promotion, and criteria for employee rankings). In order to buttress interview results, publicly available literature such as firms' annual securities reports, company reports, as well as information provided on home websites, were also closely studied.

Japanese corporations traditionally hire large numbers of new graduates from universities, training and promoting them in-house. The goal is to match individual skills to firm-specific requirements through job rotation based on LTE (Koike 1987; Koike et al. 2001). In contrast, in other advanced nations it is common for firms to hire employees with specialized backgrounds and then compensate them for the specific job performed. In the latter instance, job rotation is much less common and LTE is not considered a prerequisite. Thus, to the extent changes in HRM are designed to establish more job-based policies, and to deemphasize internal promotion or long-term employment, such changes may be regarded as deviation or departure from traditional Japanese HRM policies and practices.

Presented immediately above (Table 1) are brief profiles of the companies studied during the research period. Annual sales figures cover the period ending on March 31, 2015, while the numbers of employees ${ }^{4}$ noted are as of March 31, 2015.

Auto companies engage in relatively straightforward production and sales activities which are common across the sector. Variation among firms in the areas of skill formation and human resource requirements is therefore relatively limited, particularly in comparison with other industries (e.g., electronics) where firms have much more diversified businesses. Thus, linkages between HR policies, and product or industry characteristics, can be clearly interpreted. Furthermore, given the competitive advantage the sector has long enjoyed in global product markets, these findings should help provide a firm grounding from which to predict future trajectories of change and also present a depiction of overall divergence within employment systems in Japan.

\section{Results}

In order to provide an overall picture of HRM at the firms researched, findings from the case study are summarized below according to HRM policy and practice for core white collar (regular) employees (refer to Table 2).

\footnotetext{
${ }^{4}$ Figures in the table show numbers of regular employees. According to respective annual securities reports, the ratios of non-regular workers in surveyed firms range from less than $10 \%$ at $\mathrm{C} \mathrm{Co}$. to $26 \%$ at E Co., substantially lower than the national average of $39 \%$. A Co., E Co., and G Co, explicitly state such figures include part time workers, dispatched workers and fixed term workers, while C Co. includes part time workers and fixed term workers. B Co. and D Co. only state that the figures include temporary workers and declined to provide further details.
} 
Table 2 Summary of HRM policies and practices

HR practices Summary

Primary recruiting policies

Retirement and yakushoku-teinen ${ }^{\mathrm{b}}$
All firms primarily hire new graduates, while mid-career hires account, on average, for roughly $20-30 \%$ of total hiring (albeit, with some individual variation among firms). B Co. recently hired 200 mid-career applicants, versus 400 new graduates, the largest ratio of mid-career hires among Japanese firms studied. This approach is based on a core principle espoused by B Co.'s founder: that mixing people of various professional backgrounds will strengthen a firm's organization (though, it should be noted, B. Co. usually targets younger employees below the managerial level). A Co. was found to be the firm most focused on new graduate hiring, taking on 10-20 mid-career applicants versus 500-600 new graduates (with higher education degrees). During the mid-2000s, however, A Co. hired 200 or more mid-career applicants alongside 1000 new graduates. For most of the firms there are two purposes in mid-career hiring: improve the 'age curve' of employees ${ }^{\mathrm{a}}$, and strengthen specific areas of expertise. To fulfil the latter need, for example, engineers with electric and ICT backgrounds, who often come from ailing Japanese consumer appliance companies, are being targeted. G Co. said that they have also seen CVs of candidates from TEPCO after the nuclear disaster of 2011. Roughly $45 \%$ of hires by D Co. (a firm under foreign ownership) are of mid-career applicants

Retirement age is set at 60 in all companies while continuous employment under separate contract is provided up to age 65 or up to 62 , in line with legal requirements ${ }^{\mathrm{c}}$. In most Japanese firms, a majority of white collar workers (particularly engineers) continue working until, or even past, retirement age. For example, at B Co. most employees work until 60, with 50-60\% choosing to work until 65 . B Co. was considering raising its retirement age to 65 (and the firm did, in fact, raise it in 2017). Five firms excluding E Co. (a Japanese truck and bus manufacturer) and G Co. (a Japanese auto parts maker) have abolished yakushoku-teinen entirely or in part. A Co. ended it for group heads but continues to employ the practice for general managers at age 57 and managers at 55. Yakushoku-teinen is age 58 at E Co. and 55 at G Co., for all employees. For all firms still practicing yakushokuteinen, employees reaching designated ages are often offered managerial positions within extended ILMs (subsidiaries, affiliated companies and sometimes client companies). B Co. has entirely abolished yakushoku-teinen but the practice at the firm had been unusual: employees would lose titles after a set number of years had passed without promotion (after which they stopped advancing, regardless of age). This indicates that B Co.'s promotion policy has been the most performanceoriented among Japanese firms covered in this study 
Table 2 (continued)

HR practices

Skill formation and job rotation

Compensation, criteria for employee ranking systems, and promotion policies
Summary

Regular job rotation is practiced at four of the firms (A Co., B Co., E Co. and G Co.) none of which has experienced foreign ownership; however, job rotation across company divisions (or different functions) is not common during employees' growth stages, while scope of rotation tends to expand as an employee's seniority increases. B Co. conducts rotation but it's not controlled by HR, while individual employee preference may be accommodated if business requirements are also met. The firms currently under foreign ownership (D Co. and $\mathrm{F} \mathrm{Co.),} \mathrm{and} \mathrm{the} \mathrm{firm} \mathrm{with} \mathrm{past} \mathrm{experience} \mathrm{with} \mathrm{foreign} \mathrm{owner-}$ ship (C Co.), conduct rotations only as deemed necessary and mainly for talent management purposes for selected staff. C Co. introduced recruitment by occupational field when the firm was under the control of an American company, but discontinued the policy after the two separated

In line with Japanese practices, all companies provide bonuses equivalent to several months of annual base salary except for E. Co., which once experienced severe financial difficulties and decided to introduce strongly performance-oriented compensation schemes (for the sake of reducing overall costs rather than motivating high performers). In the determination of bonus amount, however, firms' performance rather than individual's are given more weight. 6 out of 7 firms introduced annually determined salaries at least for managerial staff which, in theory, can be reduced if performance is weak or employees take less demanding jobs. Criteria for employee ranking were found to be heterogeneous among firms and between managerial and non-managerial staff. A common trend is for senior management promotion to be reflective of roles and responsibilities, as well as the availability of positions, while for regular staff ability or competency remain the chief criteria. Promotion has become more selective (if not slow). The practice of considering tenure continues to be observed at A Co., E Co. and G Co. but only for younger staff. F Co. claims there is significant difference in the speed of promotion between their German operations and F Co.; promotion to manager is, on average, 10 years younger in Germany than in Japan 
Table 2 (continued)

\begin{tabular}{|c|c|}
\hline HR practices & Summary \\
\hline Foreign operations management & $\begin{array}{l}\text { All companies (except for E Co., which still recorded more than } \\
\text { half of its sales in Japan) have developed linkages between } \\
\text { ranking systems in Japan and those at overseas locations (if } \\
\text { not unifying them), while core positions in global opera- } \\
\text { tions are recorded and supervised by HR at HQ. These firms } \\
\text { have also developed global HR programs_-for example, on } \\
\text { global leadership, global succession planning or global talent } \\
\text { management-in order to expedite development of human } \\
\text { resources in Japan and overseas who can manage expand- } \\
\text { ing global operations. One firm (A Co.) has introduced, and } \\
\text { another (F Co.) was introducing, person- or ability-based } \\
\text { (rather than job-based) criteria into senior management ranks } \\
\text { abroad. A Co. stressed the importance of LTE even at overseas } \\
\text { operations. Both A Co. and B Co. stated that globalization of } \\
\text { Japanese staff is more important than enhancing the diversity } \\
\text { of human resources }\end{array}$ \\
\hline
\end{tabular}

\begin{abstract}
${ }^{\mathrm{a} J a p a n e s e}$ firms traditionally hire similar numbers of new graduates each year, most of whom continue to work until retirement age, firms maintaining similar numbers of employees by age (as far as the numbers of new graduate hires remain constant). However, these numbers can fluctuate yearly, in line with prevailing economic conditions, forming distorted age distributions of employees. Thus, firms sometimes try to correct for such unbalanced distributions by hiring mid-career applicants, who belong to an age group in short supply, in order to maintain consistent numbers of total employees over time, which is deemed important, particularly for firms practicing LTE.

${ }^{b}$ The practice of depriving senior employees of their titles, as they reach designated ages, without promotion to executive or board member positions. This policy helps firms transfer managerial positions to younger staff and has been commonly practiced among large Japanese firms that traditionally promote employees based on age or tenure. In other words, it signals the nenko-orientation of firms' HR policies.

'Partial Amendment to the Act on Stabilization of Employment of Elderly Persons, enacted in 2013. The act requires firms to provide all employees who want to keep working beyond the retirement age of 60 opportunities to remain employed up to age 65. (There is a progressive increase in this age over time-from 61 in 2013 to 65 in 2025-in line with increases in pensionable ages.) Since extension of the retirement age, per se, is not required, many firms maintain retirement ages of 60 , rehiring workers who reach this age under separate contracts up to either age 65 , or up to the legally required age, which is 62 between April 2016 and April 2019.
\end{abstract}

\title{
5 Discussion
}

Auto sector interviews revealed rather heterogeneous HRM policies and practices, depending on such factors as: ownership history, size of overseas operations, financial condition, the management philosophy of a firm's founder(s), and so on. At the same time, companies in this sector do share some key HRM characteristics.

\subsection{Recruitment and retirement policies}

Most importantly, firms in this sector exhibited common trends in recruitment and retirement policies, which are the most crucial factors shaping the overall HR model: All of the firms, including D Co. and F Co. (with significant foreign 
ownership), primarily depend on new graduate hiring in their recruitment processes; and all the firms, except for these two foreign-owned firms, explicitly stated that a majority of employees continue to work until retirement age (or yakushoku-teinen), or even past this point, being rehired from age 60. Although C Co. (once partly owned by an American firm) and E Co. (a Japanese truck and bus manufacturer) had experienced substantial financial difficulties, a majority of staff (more than $90 \%$ in the case of E Co.) continue to work until retirement age. While G Co. (a Japanese auto parts manufacturer), whose HR policies remain the most traditional, is considering lowering the age for yakushokuteinen, six companies have already abolished or partly abolished the practice. This would suggest that experienced human resources are still valued in the sector-or, at least, that it is relatively less difficult to find positions internally for elder employees who possess relevant skills and experience, and are willing to work regardless of position or title. It should be noted that two companies expressed a need to dispatch experienced engineers from Japan into expanding foreign operations, a task to which elderly employees, who are close to retirement, are often assigned.

This development contrasts with the recent experiences of Japan's financial sector (Yamauchi 2013, 2016), where considerable percentages of employees (particularly at banks and securities firms) quit voluntarily, yakushoku-teinen continues to play an important role (at banks and life insurance companies), and in the case of banks elder staff who have no prospect of being promoted to executive positions are pushed out of firms into extended ILM at ages slightly above 50, before actually losing their titles. The marked difference is likely due to several factors. First, in the automobile sector long-term skill formation tends to lead to greater benefits, and engineers, if not senior administrative staff, enjoy continued opportunities to utilize their knowledge and expertise in some manner despite ongoing technological development. Second, a majority of new graduate hires have majored in engineering (or similar technology-oriented fields); thus, despite the presence of regular job rotation and HR practices which facilitate internal coordination, employees skills in this sector are relatively specialized. Third, Japanese auto companies remain highly competitive, and there are no large foreign operations in Japan absorbing Japanese employees, while overseas operations of Japanese manufacturers continue to grow, necessitating inputs from experienced staff. Fourth, foreign players expanding in Japan will try to adjust some HRM schemes to fit local market environments rather than force subsidiaries in Japan to accept HR policies just as they exist at firms' HQs; thus, divergence in HR practice between foreign and Japanese firms tends to be limited, while job change does not necessarily entail significantly better working conditions. HQs and major operations of auto sector companies are fairly dispersed across Japan, forming the backbones of several local economies and labour markets. For this reason, changing jobs to one with better conditions usually involves relocation and can be a difficult matter to decide on. As mentioned below, promotion has become more selective and so firms now have less need to strip elderly staff of their titles. 


\subsection{Employee ranking, compensation and promotion}

A number of changes were observed in criteria for employee ranking, evaluation and compensation. However, variable proportion and individual difference in actual pay continue to be limited in the sector, where at A Co., for example, annual compensation differentials among cohorts of the same rank reach, at maximum, around $10 \%$, even for managerial staff. F Co. (under German ownership) also stated that its overall performance results are approximately twice as impactful as individual performance, while D Co. (under French ownership) decided, after studying the local market environment, to introduce less aggressive, less variable compensation schemes into Japan than it employs at its HQ or subsidiaries in other countries. The resilience of existing compensation schemes was also confirmed in the area of mid-career hiring. Although each of the firms hire substantial numbers of mid-career applicants, they are assigned to an appropriate existing rank at the HQ level (if not at all subsidiary levels).

On the surface, ranking criteria appear to show marked heterogeneity. For regular staff, for example, two firms (A Co. and G Co.) have adopted criteria that are mainly ability-based, one firm (B Co.) criteria that are job and ability-based, one (F Co.) competency-based, one (D Co.) competency and performance-based, one (E Co.) ability and performance based, and another (C Co.), which for 15 years was controlled by an American company, job-based. However, in sum, and excepting $\mathrm{C}$ Co. (with its particular experience under U.S. management) firms continue to stress, or at least partly stress, competencies or abilities for non-managerial younger white collar staff. This appears to result from the importance of developing firm specific skills in this sector and reliance on new graduate-centred recruitment policies which require subsequent internal training. Such an approach is justified as necessary under Japanese education and labour market conditions, where large numbers of university and high school graduates, who generally have received little occupational training, enter the job market simultaneously, forming the largest and highest potential labour supply pool in a country with limited labour mobility. This course has been common in most other sectors as well; for example, even foreign investment banks regularly tap new university graduates in order to acquire high-potential candidates (Yamauchi 2016). In other words, local institutions provide common incentives to firms across sectors and ownership.

Another common trend observed in ranking and promotion systems is that most of the auto firms now take into consideration the element of job, or role, when making promotions to management levels (even if the primary evaluation criterion remains, at least for regular staff, ability). At the same time, despite an aging employee population, none of the companies had raised promotion ages (at least for promotions in ranks) for fear that younger staff would become less motivated, and also in the interest of internal revitalization. This has resulted in more selective promotion processes and it is actually now common to find managers supervising elder subordinates, a rare occurrence under Japan's seniority-based promotion system as strictly applied. Indeed, one company (A Co.) is even providing training on how to manage subordinates older than oneself (This company subsequently announced in 2018 it would substantially reduce the number of executive management positions 
in order to speed up decision making processes, while simplifying (broadening) the ranks for senior management in order to allow younger managers the opportunity to take executive positions). Thus, it could be that, due to selective promotion, individual wage differentials, which reflect both proportion (quantity) and speed of promotion, are expanding more significantly than annual wage differentials per se. So while nenko is no longer practiced with managerial staff, overall criteria for ranking or compensation have come to encompass more explicit 'double standards' in most firms: one standard (job or performance-centred) for managerial staff, another (ability-centred) for younger employees. ${ }^{5}$

\subsection{Job rotation}

Of the firms interviewed, four (none of which has experienced foreign management) conduct regular job rotation. However, the scope of this rotation tends to be limited to sub-functions within the same divisions or to similar occupational fields (particularly during employees' growth periods) rather than to range across broader functions or divisions - a finding that coincides with observations made by Fujimoto (1997). The case study further indicates that, among white collar employees in their growth stages, job rotation is designed to deepen individual expertise in specific skills. When these employees achieve more senior status, though, companies tend to present a broader range of possible positions to them in order to achieve a high level of synergy and coordination among various functions-which, it is hoped, will eventually spur innovation. Finally, as employees near retirement, all of the firms provide whatever positions are available in order to secure some within (extended) ILM. And yet, more diverse patterns were also observed: Despite no history of foreign ownership, B Co. does not conduct HR-controlled regular job rotation and considers individual employees' interests when determining assignments, while E Co. (a Japanese truck and bus company) conducts broad job rotation among administrative staff (if not engineering staff).

After being acquired by an American automaker, C Co. at one point introduced hiring by occupational field. However, it discontinued the practice after separating from the American firm, because C. Co. found that such hiring does not necessarily aid in acquiring the best talent from local labour markets (except in the case of certain specific and popular occupational fields such as marketing). C Co. also reactivated job rotation, which it had discontinued under American management, though job rotation now does not entail such broad shifts across multiple functions as conducted before the firm's acquisition.

\footnotetext{
${ }^{5}$ In the case of E Co., the standard involves bifurcation between professional backgrounds of employees (engineering vs. administrative).
} 


\subsection{Global HR}

Finally, it is common at the firms studied to try to unify, or at least link, employee ranks and evaluation criteria in Japan with those overseas so that core staff in all locations are managed according to similar principles, if not exactly the same ranking systems or same compensation amounts. Japanese automobile companies enjoy strong competitive positions abroad, with $70-80 \%$ of total sales coming from overseas markets; accordingly, management of overseas operations is increasingly important while global HR has been implemented at relatively early stages, at least at a substantial majority of leading firms.

This process, however, does not involve the introduction of HR policies of English-speaking countries, as observed in other sectors. Rather, this study finds the opposite flow-of 'Japanization'-towards HR practices at overseas operations. Two firms even reported introducing abroad elements of Japanese ability- and person-based criteria, and also facilitating job rotation among senior staff in order to achieve, from the firms' perspective, ideal human resource allocation (though, interviews also revealed that this is not an easy course to follow with white collar, if not blue collar, employees). A Co. in particular is committed to LTE, even at its foreign businesses. A Co. HR managers claimed that the sense (or mind-set) of being on the same boat is important for the sake of sustaining production systems, suggesting the importance of applying similar HR principles (if not practices) whether for blue collar or white collar workers, and whether for operations in Japan or abroad.

When the firm was forced to close some operations in the US, A Co. offered displaced American workers the option of moving to other plants; and, for example, approximately 100 employees did relocate from Indiana to Kentucky. A. Co.'s HR managers exhibited pride that jobs were protected in this manner at their non-unionized factories. In short, A. Co.'s recent experiences suggest that Japanese practices may be embraced abroad (at least by blue collar workers) and even in the US.

It is also interesting to note that the two most representative passenger car companies with no foreign ownership, A Co. and B Co., stressed the importance of globalizing their Japanese staff over increasing (demographic) diversity of operations in Japan. This would suggest that an ethnocentric, or standardized global approach (Bartlett and Goshal 1998) toward MNC management may continue to prevail among Japanese auto sector companies, while at the same time firms expedite training and development of staff abroad who can assume more managerial roles. The development and promotion of overseas staff, combined with unified ability-based evaluation principles for senior management, may foster transnational HRM in the future. However, judging from comments by the two most successful firms in the sector, the aim of such policy may not be the enhancement of workplace diversity, but rather the efficient diffusion of corporate culture and management practices developed in Japan into overseas operations. While firms in this sector are also actively investing in new technological fields both domestically and globally, to the extent that core production methods and related knowhow continue to derive from domestic operations, the policy of focusing on globalizing Japanese staff would appear legitimate and justified. 


\section{Conclusion}

The goal of this study has been to investigate developments in HRM policies and practices among major Japanese auto sector companies. It has observed gradual, incremental change in some key HRM practices as well as the introduction of global HR programs at relatively early stages (in comparison with Japanese firms in comparable industries). It has also confirmed that globalization of HRM in Japan's auto sector is materializing in such a way as to preserve key existing practices within Japanese operations. Furthermore, while globally unified criteria or principles for ranks or grades for managerial positions are being introduced at most firms, this does not involve a transformation of practices in Japan but rather the introduction of Japanese practices into foreign operations (as explicitly observed in the introduction of ability- or person-based criteria to overseas management at two firms researched). Thus, the direction of global HR in the auto sector differs markedly from that observed, for example, at Nomura Securities or Takeda Pharmaceutical Co., where global HR is associated with departure from the traditional Japanese model.

The study's findings also confirm that there have been similarities and differences in HRM development among sectors. For example, more selective promotion and greater reliance on job- or role-based ranking criteria have become common among managerial staff at Japanese companies, across industries. This may be seen as a response to aging employee populations (the result of slower economic growth in Japan as well as institutional requirements necessitating the provision of continuous employment opportunities for senior staff), making it difficult for firms to maintain nenko for managerial staff. That is, the observed changes appear to stem mainly from domestic factors, and such factors tend to exert similar pressures on all companies operating in Japan, pushing firms across sectors into making homogeneous changes.

In contrast, divergent change observed by sector reflects the relative global competitive strengths or weaknesses firms display in deregulated sectors, which are subject to international competition; firms in weak sectors face pressures exerted by foreign players maintaining employment practices substantially different from their Japanese counterparts-practices which, if attractive, can be influential in local labour markets. Such impacts are reflected in the rapidly expanding divergence observed in skill formation and compensation among Japanese financial sector companies, where intensified competition over human resource acquisition, and increased labour market liquidity, have led to the introduction of new HR policies such as specialized career courses and more individualized compensation packages (Yamauchi 2016). These schemes, aimed at attracting and retaining highly capable staff, have sometimes come at the expense of job security, thus eroding traditional LTE practice. In the case of auto sector companies, however, LTE continues to be the core feature of employment system, although the criteria for employee ranking exhibit substantial deviation and divergence from nenko in the traditional sense.

Based on these findings, this study was able to confirm that, though both domestic and global pressures facilitate change, it is more global pressures that 


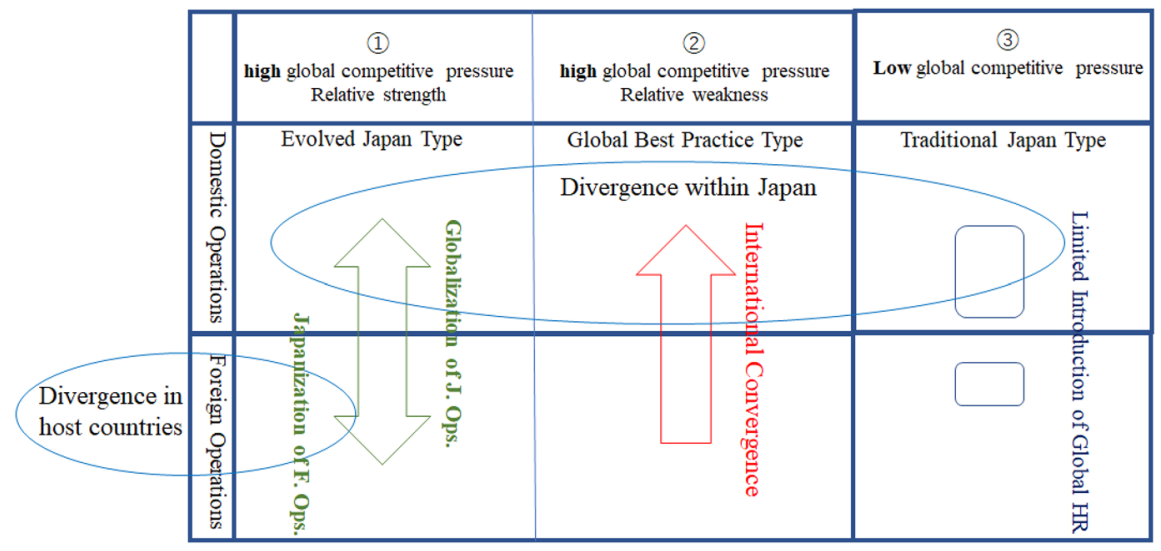

Fig. 2 Overview of divergence in employment systems and direction of global HR unification. Global best practice in (2) indicates practices deemed successful in an individual sector

have triggered divergence in HRM practice. Companies in comparatively weak positions tend to adjust HRM practices to those of foreign players as the latter become dominant or at least effective within local labour markets. In contrast, within sectors where Japanese players are in strong positions, foreign firms may adjust HRM practices in line with local norms. Accordingly, despite ongoing radical innovation or suggested possibility of disruptive change in auto manufacturing (self-driving cars, all-electric vehicles, and the like), such technological development does not appear to be transforming overall HRM practices for rank and file employees of auto firms in Japan.

Some critics may see this as evidence of slow progress in HRM reforms necessary for firms to adapt to new environments. However, for companies in this sector, all vying to remain up to speed technologically while maintaining strong competitive positions, the road forward-the nature and degree of change which is in order-is not necessarily obvious. Looking at developments abroad, it is interesting to note that newly established car companies such as Tesla Motors, which have introduced cutting-edge technologies, often face obstacles to ramping up production and achieving stable operations (despite exceptional performance in stock markets, albeit with significant volatility). Even German companies, in the wake of increased competition from Japanese lean management, were forced to modify production methods and HRM to improve productivity (Haipeter et al. 2012).

Reviewing the abovementioned findings, we may conclude that, to the extent a particular market is deregulated (institutional pressures are low) and so subject to significant international competition, relative institutional advantages or disadvantages will manifest themselves and become factors in determining the direction of HRM policy. Japanese firms enjoying relative competitive advantage try to diffuse key native policies into overseas operations ('Japanization'), thereby fostering divergence in host countries, while at the same time evolving domestic operations to meet new HR challenges in order to manage the complexity of globally expanded 
operations. In short, global HR policy does not always lead to the introduction of foreign practices into Japanese operations.

Based on these findings, the author presents above a hypothetical model depicting divergence in employment systems observed among large Japanese firms (Fig. 2). The model consists of three (simplified) patterns, each indicating a different trajectory of change as well as the direction of unification in HR policies associated with the introduction of global HR. In the deregulated sectors, which are subject to global competitive pressure, relative competitive strengths and weaknesses manifest themselves, forcing firms within strong sectors to globalize their HR policies at HQ to meet the new challenges and complexity of global operations (a result of their robust presence in overseas markets). Such global HR policies include Japanization of foreign operations, which causes divergence in employment systems in host countries (corresponding to (1) in Fig. 2). In the weak sectors, however, changes in HR policies at HQ are often associated with the introduction of global best practices unique to particular sectors or sub-sectors (as opposed to universally applicable best practices suggested by Kerr et al. (1960)); such global best practices increases divergence in employment systems in Japanese labour markets (corresponding to (2) in Fig. 2). Lastly, in those sectors experiencing limited or no global competitive pressures-a result of prevailing institutional arrangements-relative strengths or weaknesses do not manifest themselves and so do not become a key factor influencing HR policies. Firms in these sectors are thus much less motivated to change HR policies or introduce global HR (corresponding to (3) in Fig. 2).

Finally, there are of course limitations to this study. Due to a lack of broad employee involvement, interviews relied on input from respective HR managers and, as it was up to each manager to decide how much information to impart, obtaining consistent levels of depth and specificity across responses proved challenging. Nevertheless, this study has been able to identify, and offer a basis for understanding, growing divergence currently observable in HRM policy at Japanese firms, while also pointing towards possible patterns of convergence across countries.

\section{Compliance with ethical standards}

Conflict of interest No potential conflict of interest was reported by the author.

Open Access This article is licensed under a Creative Commons Attribution 4.0 International License, which permits use, sharing, adaptation, distribution and reproduction in any medium or format, as long as you give appropriate credit to the original author(s) and the source, provide a link to the Creative Commons licence, and indicate if changes were made. The images or other third party material in this article are included in the article's Creative Commons licence, unless indicated otherwise in a credit line to the material. If material is not included in the article's Creative Commons licence and your intended use is not permitted by statutory regulation or exceeds the permitted use, you will need to obtain permission directly from the copyright holder. To view a copy of this licence, visit http://creativecommons.org/licen ses/by/4.0/. 


\section{References}

Abe M, Hoshi T (2007) Corporate finance and human resource management in Japan. In: Aoki M, Jackson G, Miyajima H (eds) Corporate governance in Japan-institutional change and organizational diversity. Oxford University Press, Oxford, pp 257-281

Ahmadjian CL, Robbins GE (1990s) A clash of capitalisms: foreign shareholders and corporate restructuring in 1990s Japan. Am Sociol Rev 70(3):451-471

Ahmadjian CL, Robinson P (2001) Safety in numbers: downsizing and the deinstitutionalization of permanent employment in Japan. Adm Sci Q 46(4):622-654

Appelbaum R, Batt R (1994) The new Americal workplace: transforming work systems in the United States. ILR Press, Ithaca

Bartlett CA, Ghoshal S (1998) Managing across borders: the transnational solution. Harvard Business School Press, Boston

Casper S, Whitley R (2004) Managing competences in entrepreneurial technology firms: a comparative institutional analysis between German, Sweden and the UK. Res Policy 33(1):89-106

Cole R (1971) Japanese blue collar - the changing tradition. University of California Press, Berkeley

Conrad H, Meyer-Ohle H (2019) Overcoming ethnocentric firm?: Foreign fresh university graduate employment in Japan as a new international human resource development method. Int J Hum Resour Manage 30(17):2525-2543

Dore R (1973) British factory-Japanese factory, the Origins of national diversity in industrial relations. University of California Press, Berkeley

Fujimoto T (1997) Evolution in production system: organizational capability and process of emergence at Toyota [in Japanese: Seisan shisutemu no shinkaron: Toyota jidōsha ni miru soshiki nōryoku to sōhatsu purosesu]. Hakutōshobo, Tokyo

Fujimoto T (2001) Production management for beginners II: management practices of production resources [in Japanese: Seisan manejimento nyūmon II Seisan shigen gijutsu kanri hen]. Nihon Keizai Shinbunsha, Tokyo

Fujimoto T (2003) Competition in capability building: Why Japanese automobile industry is strong [in Japanese: Nōryoku kōchiku kyōsō-Nihon no jidōsha sangyō ha naze tsuyoinoka]. Chūōkōron Shinsho, Tokyo

Fujimoto T (2018) A design-information-flow view of industries, firms, and sites. In: Fujimoto T, Ikuine F (eds) Industrial competitiveness and design evolution. Springer, Tokyo, pp 5-41

Haipeter T, Jürgens U, Wagner K (2012) Employment relations in the banking and automotive industries in Germany. Int J Hum Resour Manage 23(10):2016-2033

Hall PA, Soskice D (2001) Varieties of capitalism-the Institutional foundation of comparative advantage. Oxford University Press, Oxford

Hirano M (2006) Japanese HRM: process and functionality of evolutionary model [in Japanese: Nihongata jinjikanri: Shinkagata no hasseipurosesu to kinōsei]. Chuō-Keizaisha, Tokyo

Hunter LW, Katz HC (2012) The impact of globalization on human resource management and employment relations in the US automobile and banking industries. Int J Hum Resour Manage 23(10):1983-1998

IQVIA (2016) Topline market data [in Japanese: Topline shijō data]. https://www.ims-japan.co.jp/japan ese/topline/dl/ToplineData_CY_2015.pdf

Jackson G (2007) Employment adjustment and distributional conflict in Japanese firms. In: Aoki M, Jackson G, Miyajima H (eds) Corporate governance in Japan: institutional change and organizational diversity. Oxford University Press, Oxford, pp 282-309

Jacoby S (2007) Convergence by design: the case of CalPERS in Japan. Am J Comparative Law 55(2):239-293

Katz HC, Darbishire O (1999) Converging divergences: worldwide changes in employment systems. Cornell University Press, Ithaca

Kerr C, Dunlop JT, Harbison FH, Myers CA (1960) Industrialism and industrial man: the problem of labour and management in economic growth. Heinemann Education, London

Keizai T (2015) Data book series 8: List of foreign companies [in Japanese: data bank series 8 Gaishi-kei kigyō sōran]. Tōyō Keizai Shinpōsha, Tokyo

Koike K (1987) Human resource development and labour management relations. In: Yamamura K, Yasuba Y (eds) Political Economy of Japan. The domestic transformation, vol 1. Stanford University Press, Stanford, pp 289-330 
Koike K (1999) Economics of job [in Japanese: Shigoto no keizaigaku]. Tōyō Keizai Shinpōsha, Tokyo

Koike K (2008) Human resource development in Japanese companies abroad [in Japanese: Kaigai nihon kigyo no jinzai keisei]. Tōyo Keizai Shinpōsha, Tokyo

Koike K, Chūma H, Ota S (2001) Skills in manufacturing: at workshops in automobile industry [in Japanese: Monozukuri no ginō-Jidōsha sangyō no genbade]. Tōyō Keizai Shinpōsha, Tokyo

Kubo K (2018) The effect of corporate governance on firms decent work policies in Japan. Asia Pacific J Hum Resour 56:450-473

Kumazawa M, Yamada J (1989) Jobs and skills under the lifelong nenko employment practice. In: Wood S (ed) The transformation of work. Unwin Hyman, London

MacDuffie JP, Krafcik JF (1992) Integrating technology and human resources for high performance manufacturing: evidence from the international auto industry. In: Kochan TA, Useem M (eds) Transforming organizations. Oxford University Press, New York, pp 209-225

MediSearch (2016) The number of MRs in pharmaceutical companies [in Japanese: Seiyaku kigyō MRsū]. Medisearch Kabushikigaisha, Tokyo https://www.medisearch.co.jp/doukou_MRnumber. html

Miyajima H, Haramura K, Inagaki K (2003) Corporate governance reform in progress and revival of Japanese firms [in Japanese: Shintensuru kōporēto gabanansu kaikaku to nihonkigyō no saisei]. Ministry of Finance, Policy Research Institute, Tokyo

Miyamoto M (2006) Transformation of corporate governance and direction of Japanese management [in Japanese: Kōporēto gabanansu no henyō to nihonteki keiei no yukue]. Rōdō seisaku kenkyū hōkokusho 61:99-191. The Japan Institute for Labour Policy and Training, Tokyo

Morishima M (1995) Embedding HRM in a social context. Br J Ind Relat 33(4):617-640

Olcott G (2009) Conflict and change: foreign ownership and the Japanese firm. Cambridge University Press, Cambridge

Ono H (2007) Careers in foreign-owned firms in Japan. Am Sociol Rev 77(2):267-290

Porter M, Takeuchi H (2000) Can Japan complete?. Diamond, Tokyo

Rōmu-Gyōsei (2004) New wage systems for managers at Nissan [in Japanese: Nissan jidōsha no shinkanrishoku chinginseido-Yakuwari-betsu no shin-seido dōnyū]. Rōsei-Jihō 3622:2-15

Sako M (1997) Foreword: Part I—Professor Hiroshi Hazama on the firm as a family. In: Hazama H (ed) The history of labour management in Japan. Macmillan Press Ltd, London

Suda T (2015) Changing 'Japanese' corporate strategy: Analysis in the light of complementarity between management strategy and HRM strategy [in Japanese: Nihongata senryaku no henka: Keieisenryaku to jinjisenryaku no hokansei kara saguru]. Tōyō Keizai Shinpōsha, Tokyo

Suda T (2017) Comparison of human resource management between the pharmaceutical and electrical industries in Japan. World Manage J 8(1):170-188

Thelen K (2014) Varieties of liberalization and the new politics of social solidarity. Cambridge University Press, New York

Turner A (2001) Just capital: the liberal economy. MacMilan, London

Waldenberger F (2016) Global human resource management: the challenge for Japanese multinational firms. J Manage Philos 13(2):74-82

Whitley R (1999) Divergent capitalism: the social structuring and change of business systems. Oxford University Press, Oxford

Yamauchi M (2013) Japanese employment systems: growing divergence and globalization [in Japanese: Koyō sisutemu no tayōka to kokusaiteki shūren]. Keio University Press, Tokyo

Yamauchi M (2016) Employment systems in Japan's financial industry: globalization, growing divergence and institutional change. Br J Ind Relat 54:522-551

Yamauchi, M. (2018) Success of SAP: an analysis from German institutional environment [in Japanese: SAP no seikō: Doitsu Seido Kankyō karano Ichikōsatsu]. SEC J14 (1): 80-87 https://www.ipa. go.jp/files/000068596.pdf

Yashiro A (2017) Where is Japanese employment relations going: Human resource acquisition across Japanese and foreign firms in automobile and financial industries [in Japanese: Nihonteki koyō seido ha dokoni mukaunoka: Kinyū jidōsha gyōkai no shihonkokuseki wo koeta jinzaikakutokukyōsō]. Chuo Keizai Sha, Tokyo

Yin YK (2003) Case study research: design and methods, 3rd edn. Sage Publications, Thousand Oak

Publisher's Note Springer Nature remains neutral with regard to jurisdictional claims in published maps and institutional affiliations. 